\title{
MODEL MATEMATIKA SEDERHANA REDAMAN GETARAN PADA SAYAP PESAWAT TERBANG
}

\author{
Rukmono Budi Utomo \\ Universitas Muhammadiyah Tangerang \\ Email : rukmono.budi.u@mail.ugm.ac.id
}

\begin{abstract}
We have known that when the plane encountered turbulence or in a hard landing, the aircraft engine will swing to dampen vibrations of the aircraft wing. Thus, based on rights, this research is investigating and constructing mathematical model of aircraft wing vibration. In this research, we described not only the creation of mathematical models, but also the analysis of the model and its interpretation.
\end{abstract}

Keywords: aircraft wing vibration, mathematical model.

ABSTRAK. Diketahui bahwa ketika pesawat mengalami turbulensi atau pendaratan keras, maka mesin pesawat akan berayun untuk meredam gertaran yang terjadi pada sayap pesawat. Dengan demikian berdasarkan hal tersebut penelitian ini bertujuan untuk menyelidiki dan mengkonstruksi model matematika redaman getaran pada sayap pesawat terbang. Penelitian ini tidak hanya menjelaskan pembentukan model matematika, namun juga dilakukan analisis dari model yang dihasilkan beserta interpretasinya.

Kata Kunci : getaran sayap Pesawat, model matematika.

\section{PENDAHULUAN}

Saat ini pesawat terbang merupakan satu-satunya alat transportasi paling efisien bagi manusia dalam melakukan perjalanan jauh melintasi daerah, negara bahkan benua. Pesawat dapat terbang karena adanya mesin pesawat yang menghasilkan dorongan sehingga terjadi momentum dan perbedaan kecepatan aliran udara di bawah dan di atas sayap pesawat. Hukum Bernoully menyatakan bahwa kecepatan udara yang besar akan menimbulkan tekanan udara yang kecil sehingga tekanan udara di bawah sayap menjadi lebih besar dari sayap pesawat bagian atas. Berdasarkan hal tersebut akan timbul gaya angkat (lift) yang menjadikan pesawat dapat terbang. Selain mesin, terdapat bagian-bagian penting lainnya yang mendukung pesawat dapat terbang. Bagian-bagian penting itu antara lain: badan pesawat (fuselage) yang didalamnya terdapat ruang kemudi pilot 
(cockpit) dan penumpang, sayap pesawat (wing) yang memuat aileron dan flap yang masing-masing berfungsi sebagai rolling pesawat dalam bergerak ke kiri kiri dan kanan serta untuk menambah luas area sayap (coefficient lift) yang berguna untuk menambah gaya angkat pesawat (Dunia Baca, 2012). Selain itu bagian penting lainnya dalam pesawat adalah ekor yang berfungsi sebagai anggukan peswat dalam arah naik dan turun dan roda pesawat yang berfungsi dalam pendaratan atau lepas landas.

Meski merupakan alat transportasi yang efisien dan cepat bukan berarti pesawat terbang tidak memiliki hambatan. Ancaman akan cuaca buruk atau arus angin yang terlampau kencang akan membuat peswat mengalami guncangan bahkan turbulensi. Kemungkinan akan bahaya ini tentu saja telah diperhitungkan dan diantisipasi oleh para produsen pesawat. Berbagai sistem keamanan dirancang dalam menghadapi kemungkinan timbulnya getaran pesawat salah satunya adalah menempatkan mesin pada bawah sayap pesawat.

Mesin peswat yang ditempatkan pada bagian bawah sayap dimaksudkan sebagai bandul peredam yang akan berayun ketika muncul getaran pada sayap pesawat. Peredaman ini sangatlah penting agar getaran yang terjadi pada sayap pesawat tidak terus terjadi dan segera hilang. Apabila tidak adanya sistem redaman, maka penumpang akan mengalami guncangan dan sayap pesawat dapat patah karena getaran yang terus diterimanya.

Penelitian ini bertujuan memahami dan memodelkan secara matematis dari redaman getaran pada sayap pesawat. Dalam menyusun model redaman getaran ini, peneliti menganalogikan mesin pesawat sebagai peredam yang ditempatkan pada sayap pesawat memiliki kesamaan sifat seperti pegas dengan redaman. Dengan demikian berdasarkan hal tersebut model yang dibangun diturunkan dari model pegas dengan redaman tersebut. Dalam penelitian ini juga akan dilakukan analisis dari model yang telah terbentuk beserta interpretasinya.

Dalam menyusun model redaman getaran pada sayap pesawat ini, terlebih dahulu peneliti mengenalkan hukum-hukum fisika yang terkait seperti Hukum Newton, Hooke, gaya fluida, gaya sinusoidal, sifat-sifat dan model pegas sederhana tanpa redaman, serta model pegas dengan redaman. Penelitian serupa 
yang telah dilakukan antara lain oleh Mohamad Ardi Cahyono dan Agus Basuksti dengan judul penelitian Penentuan Frekuensi alamiah Sayap Pesawat Latih Dasar KT-1B Menggunakan Metode MYKLESTAD dan hasil penelitiannya terbit pad jurnal Angkasa Volume 2 edisi bulan april 2010. Lebih lanjut, beberapa buku penunjang dibutuhkan dalam penyusunan model matematika redaman getaran pada sayap pesawat ini, antara lain buku Mathematical Models: Mechanical Vibration, Population Dynamicsand Traffic Flow karya Richard Haberman, Elementary Differential Equation and Boundary Value Problem karya Boyce dan Richard, Chaos and Introduction to Dynamical System karya Alligood, Sacer dan Yorke serta buku Buku Pemodelan Matematika, Analisis dan Aplikasinya karya Widowati dan Sutimin, serta buku-buku lainnya yang dapat dibaca dalam daftar pustaka.

\section{HASIL DAN PEMBAHASAN}

Diketahui bahwa pesawat umumnya memiliki mesin dibawah kedua sayapnya. Dengan suatu faktor tertentu, pesawat dapat mengalami getaran yang disebabkan oleh guncangan baik saat lepas landas (take off), saat mengudara maupun saat pendaratan (landing). Banyak faktor penyebab itu semua diantaranya beban pesawat yang terlalu berat, kondisi landasan pacu yang kurang baik, ganguan cuaca, maupun disebabkan oleh komposisi material penyusun pesawat itu sendiri. Getaran pada pesawat biasanya dialami pada bagian-bagian tertentu dan sensitif seperti pada bagian sayap, sambungan ekor, kokpit maupun pada badan pesawat.

Mesin pesawat yang diletakan pada bagian bawah sayap dimaksudkan apabila terjadi getaran karena salah satu dari faktor diatas, maka mesin dapat bertindak sebagai suatu instrumen yang dapat mengurangi (reduce) getaran tersebut. Sehingga sekalipun masih mengalami getaran, maka hal tersebut masih berada pada batas ambang toleransi besarnya getaran yang dapat dialami oleh pesawat.

Peneliti dapat memandang topik ini dengan memanfaatkan apa yang diketahui pada sistem massa pegas dengan redaman. Pemanfaatan ini didasari 
bahwa sayap pada pesawat memiliki karakteristik tipis dan lentur sehingga membentuk suatu sistem vibrasi teredam dengan frekuensi redaman kurang (under damp) yang dapat dimodelkan seperti gambar di bawah ini

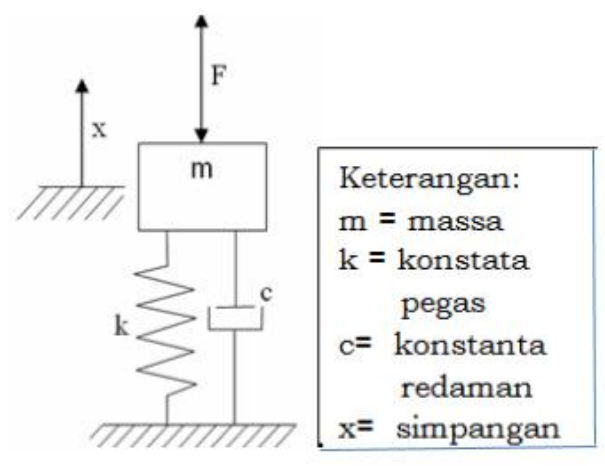

Gambar: sistem massa pegas dengan redaman

Dalam penelitian kali ini peneliti menganalogkan bahwa mesin yang berada pada bawah sayap pesawat adalah seperti peredam dalam model pegas dengan redaman ini. Sehingga dengan demikian model pegas dengan redaman ini dapat pula dianggap sebagai model getaran pada sayap pesawat dikarenakan kemiripan sifat.

Sebelum membahas sistem massa pegas dengan redaman, akan dikenalkan terlebih dahulu mengenai sistem massa pegas klasik tanpa redaman. Newton merumuskan gaya $F$ yang terjadi pada pegas dengan satu massa dirumuskan sebagai perkalian antara massa $m$ dengan percepatan $a$, atau secara matematis dituliskan sebagai $F=m a($ Haberman, 1971). Karena percepatan merupakan turunan kedua jarak terhadap waktu atau $a=\frac{d^{2} x}{d t^{2}}$, maka gaya yang bekerja pada pegas dengan satu massa menurut Newton adalah $F=m \frac{d^{2} x}{d t^{2}}$, dengan $x$ merupakan variabel posisi horizontal dan $t$ merupakan variabel waktu (Widowati, 2013) .

Hooke berpendapat bahwa ketika pegas ditarik atau didorong, maka pada saat yang bersamaan, pegas menghasilkan suatu gaya untuk mengembalikan bentuknya seperti sedia kala. Gaya ini memiliki arah berlawanan dari tarikan atau 
dorongan dan disebut sebagai gaya pemulih atau restoring force (Alligood, 1993). Gaya pemulih ini diformulasikan sebagai $F=-k x$, dengan $k$ merupakan suatu konstanta pemulih (Agarwal, 2008). Dengan demikian berdasarkan hal tersebut model sistem pegas satu massa tanpa redaman adalah

$$
m \frac{d^{2} x}{d t^{2}}=-k x \text { atau } m \frac{d^{2} x}{d t^{2}}+k x=0
$$

yang merupakan Persamaan Differensial (PD) orde dua homogen (Boyce, 1992). Solusi dari persamaan (1) tersebut adalah $x(t)=A \sin \omega t+B \cos \omega t$ yang bersifat sinusoidal dengan periode, jumlah periode dalam $2 \pi$ satuan, dan frekuensi dalam osilasi sistem pegas ini masing-masing adalah $T=\frac{2 \pi}{\omega}, \omega=\frac{2 \pi}{T}$, dan , $f=\frac{1}{T}$, dengan $\omega=\sqrt{\frac{k}{m}}($ Coddington, 1961).

Apabila model sistem massa pegas diberikan redaman, maka gaya peredam juga berlaku pada massa selain gaya yang disebabkan oleh peregangan pegas.Lebih lanjut apabila sistem ini berada dalam suatu fluida, maka benda akan mendapatkan peredaman karena kekentalan fluida. Gaya akibat kekentalan ini sebanding dengan kecepatan benda dan di formulasikan dengan $F_{d}=-c \frac{d x}{d t}$, dengan $c$ merupakan koefisien peredam dengan satuan $N \frac{s}{m}$ (Cahyono, 2010). Berdasarkan hal tersebut model massa pegas dengan redaman karena kekentalan fluida adalah

$$
m \frac{d^{2} x}{d t^{2}}+k x=-c \frac{d x}{d t} \text { atau } m \frac{d^{2} x}{d t^{2}}+c \frac{d x}{d t}+k x=0 \ldots(2)
$$

yang merupakan PD orde dua homogeny (Boyce 1992).

Pada kenyataannya, terdapat gaya lain yang berpengaruh pada model ini, gaya tersebut adalah gaya luar yang berbentuk sinusoidal dan dinyatakan sebagai $F=F_{0} \cos \omega t$, dengan $F_{0}$ merupakan besarnya gaya luar yang terjadi (Anonim). Berdasarkan hal tersebut, model matematis redaman getaran pada sayap pesawat 
menjadi $m \frac{d^{2} x}{d t^{2}}+c \frac{d x}{d t}+k x=F_{0} \cos \omega t$ dengan $\omega$ merupakan jumlah periode dalam $2 \pi$ satuan.

\subsection{Solusi Model}

Telah disebutkan pada pendahuluan bahwa model redaman getaran pada pesawat ini diturunkan dari model pegas dengan redaman dari fluida dan memperhatikan gaya lain seperti sinusoidal, berdasarkan hal tersebut model redaman getaran pesawat dalam penelitian ini dituliskan sebagai

$$
m \frac{d^{2} x}{d t^{2}}+c \frac{d x}{d t}+k x=F_{0} \cos \omega t \text { atau } \frac{d^{2} x}{d t^{2}}+\frac{c}{m}\left(\frac{d x}{d t}\right)+\frac{k}{m} x=F_{0} \cos \omega t \ldots(3)
$$

Misalkan $\frac{c}{m}=\psi^{2}$, dengan mengingat bahwa $\omega^{2}=\frac{k}{m}$, maka persamaan (3) dapat dituliskan sebagai

$$
\frac{d^{2} x}{d t^{2}}+\psi^{2} \frac{d x}{d t}+\omega^{2} x=F_{0} \cos \omega t
$$

Perhatikan bahwa model (4) tersebut Persamaan Differensial orde dua non homogen sehingga untuk mencari solusi dari persamaan ini, dicari dahulu solusi untuk persamaan differensial homogen dan dilanjutkan dengan mencari solusi partikulirnya. Berdasarkan hal tersebut solusi umum persamaan ini adalah jumlahan dari kedua solusi tersebut.

Untuk mencari solusi homogen dilakukan dengan membuat nol ruas kanan persamaan (4) dengan demikian diperoleh persamaan

$$
\frac{d^{2} x}{d t^{2}}+\psi^{2} \frac{d x}{d t}+\omega^{2} x=0
$$

Akar-akar persamaan karakteristik persamaan (5) adalah $r_{1}=-\frac{1}{2} \psi^{2}+\frac{1}{2} \sqrt{\psi^{4}-4 \omega^{2}}$ dan $r_{2}=-\frac{1}{2} \psi^{2}-\frac{1}{2} \sqrt{\psi^{4}-4 \omega^{2}}$ sehingga solusi homogen persamaan (5) adalah 


$$
x(t)=C_{1} e^{\left(-\frac{1}{2} \psi^{2}+\frac{1}{2} \sqrt{\psi^{4}-4 \omega^{2}}\right) t}+C_{2} e^{\left(-\frac{1}{2} \psi^{2}-\frac{1}{2} \sqrt{\psi^{4}-4 \omega^{2}}\right) t}
$$

dengan $C_{1}$ dan $C_{2}$ merupakan konstanta.

Solusi partikulir persamaan (4)dicari dengan cara trial and eror, yakni dengan memisalkan $x(t)=A \cos \omega t+B \sin \omega t$. Dengan demikian berdasarkan hal tersebut diperoleh

$$
\frac{d x(t)}{d t}=-A \omega \sin \omega t+B \omega \cos \omega t
$$

dan

$$
\frac{d^{2} x(t)}{d t^{2}}=-A \omega^{2} \cos \omega t-B \omega^{2} \sin \omega t
$$

Selanjutnya dengan mensubstitusikan $\frac{d x(t)}{d t}$ dan $\frac{d^{2} x(t)}{d t^{2}}$ ke dalam persamaan (4) diperoleh persamaan

$$
\left(B \omega \psi^{2}\right) \cos \omega t+\left(A \omega \psi^{2}\right) \sin \omega t=F_{0} \cos \omega t \ldots(7)
$$

Dengan melihat kesesuaian bentuk antara ruas kanan dan kiri diperoleh $B \omega \psi^{2}=F_{0}$ atau $B=\frac{F_{0}}{\omega \psi^{2}}$ dan $A=0$. Dengan demikian solusi partikulir persamaan (4) adalah

$$
x(t)=\frac{F_{0}}{\omega \psi^{2}} \sin \omega t
$$

Berdasarkan hal tersebut solusi umum dari persamaan (4) adalah

$$
x(t)=C_{1} e^{\left(-\frac{1}{2} \psi^{2}+\frac{1}{2} \sqrt{\psi^{4}-4 \omega^{2}}\right) t}+C_{2} e^{\left(-\frac{1}{2} \psi^{2}-\frac{1}{2} \sqrt{\psi^{4}-4 \omega^{2}}\right)} t+\frac{F_{0}}{\omega \psi^{2}} \sin \omega t \ldots(9)
$$

\subsection{Simulasi Model}

Pada bagian ini akan dilakukan simulasi atas solusi umum model redaman getaran pada sayap pesawat terbang yang telah diperoleh pada persamaan (9). 
Simulasi dilakukan untuk tiga kondisi yakni: Kondisi $\mathrm{I}(\omega=\psi)$, Kondisi II $(\omega>\psi)$ dan Kondisi III $(\omega<\psi)$ dengan nilai $x(0)=1, \frac{d x(0)}{d t}=0$ dan $F_{0}$ yang semakin besar yakni 25, 50, 100 . Hasil perhitungan simulasi model ditunjukkan pada gambar-gambar di bawah ini:

Kondisi I $\left(\omega=\psi=9, F_{0}=25 ; 50 ; 100\right)$

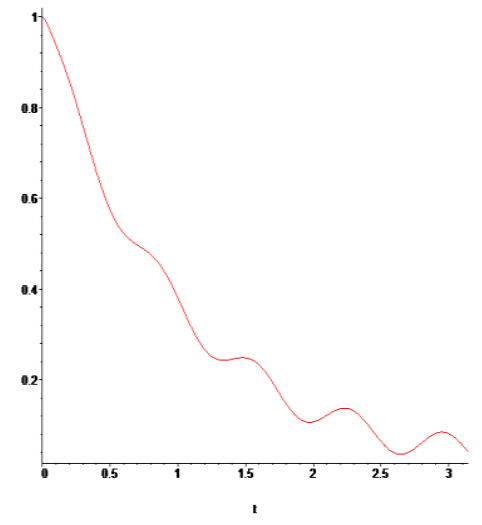

Gambar $1\left(F_{0}=25\right)$

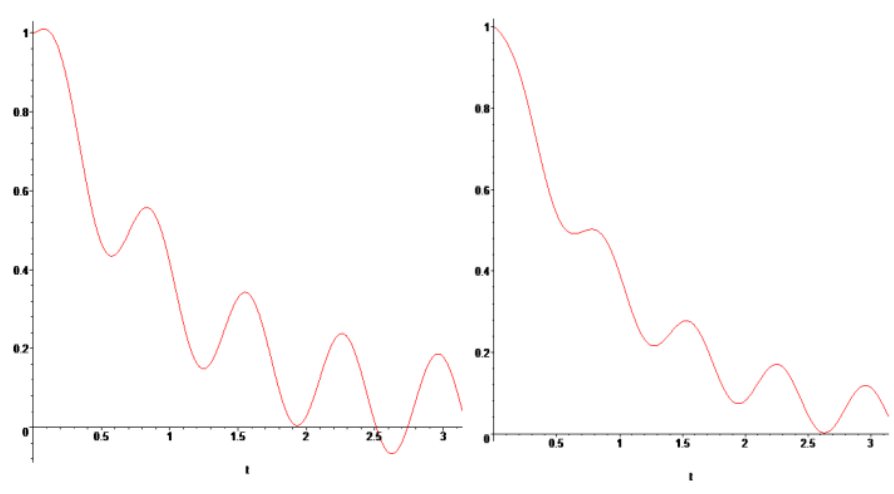

Gambar $2\left(F_{0}=50\right) \quad$ Gambar $3\left(F_{0}=100\right)$

Pada kondisi I dilakukan simulasi perhitungan untuk nilai $\omega=\psi=9$ dengan nilai $F_{0}$ yang semakin besar yakni $25,50,100$. Pada gambar 1 terlihat bahwa getaran teredam terjadi secara perlahan-lahan (tidak ekstrim) dan semakin lama getaran tersebut akan hilang meskipun dibeberapa titik terjadi peningkatan getaran yang tak lama kemudian turun kembali. Lebih lanjut gambar 2 dengan nilai gaya $F_{0}=50$ menunjukkan bahwa penurunan getaran lebih cepat dan sedikit lebih tajam dibandingkan pada gambar 1 yakni ketika keadaan dengan gaya $F_{0}=25$. Namun keadaan saat $F_{0}=50$ ini pada beberapa titik terjadi kenaikan getaran yang lebih besar dibandingakan kondisi pada saat gaya $F_{0}=25$. Pada gambar 3 saat $F_{0}=100$, penurunan getaran semakin cepat dan tajam dari dua kondisi sebelumnya, namun kenaikan getaran dibeberapa titik untuk kondisi ini juga lebih besar dari dua kondisi sebelumnya yakni ketika $F_{0}=25$ dan $F_{0}=50$ 
Kondisi II $\left(\omega=16>\psi=9, F_{0}=25 ; 50 ; 100\right)$

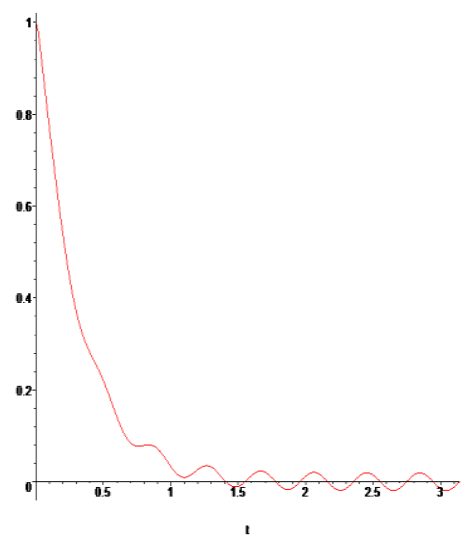

Gambar $4\left(F_{0}=25\right)$

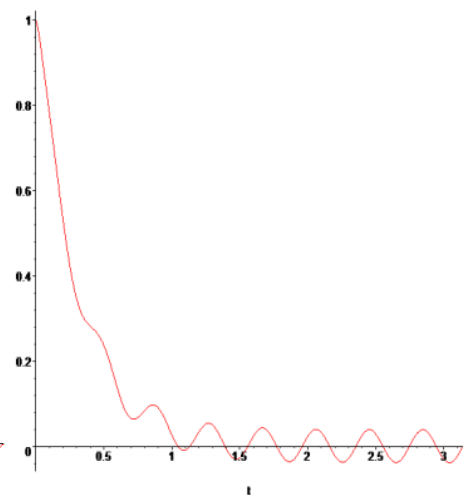

Gambar $5\left(F_{0}=50\right)$

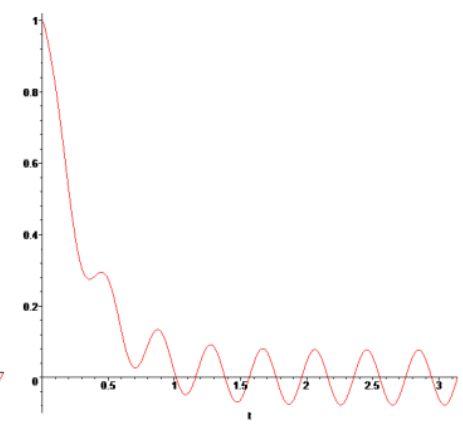

Gambar $6\left(F_{0}=100\right)$

Pada kondisi II dilakukan simulasi perhitungan untuk nilai $\omega=16>\psi=9$ dengan nilai $F_{0}$ yang semakin besar yakni $25,50,100$. Pada gambar 4 terlihat bahwa getaran teredam secara ekstrim dan cepat menghilang. Berbeda dengan kondisi I, pada kondisi II ini dengan $F_{0}=25$ dapat dikatakan getaran yang terjadi cenderung turun dan tidak terjadi kenaikan yang signifikan. Pada gambar 4 getaran berhenti pada titik sekitar $t=1.4$ dan setelahnya berosilasi secara kontinu. Lebih lanjut gambar 5 dengan nilai gaya $F_{0}=50$ menunjukkan bahwa penurunan getaran lebih cepat dan lebih tajam dibandingkan pada gambar 4 yakni ketika keadaan dengan gaya pada saat $F_{0}=50$ ini getaran lebih cepat berhenti dibandingakan kondisi pada saat gaya $F_{0}=25$ yakni pada saat $t=1.1$. Meski demikian osilasi getaran pada saat $F_{0}=50$ ini lebih cepat dibandingkan kondisi sebelumnya. Pada gambar 6 saat $F_{0}=100$, penurunan getaran lebih cepat dan tajam dari dua kondisi sebelumnya. Getaran berhenti saat $t=1$ dan setelanya getaran akan berosilasi secara kontinu. 
Kondisi III $\left(\omega=9<\psi=16, F_{0}=25 ; 50 ; 100\right)$

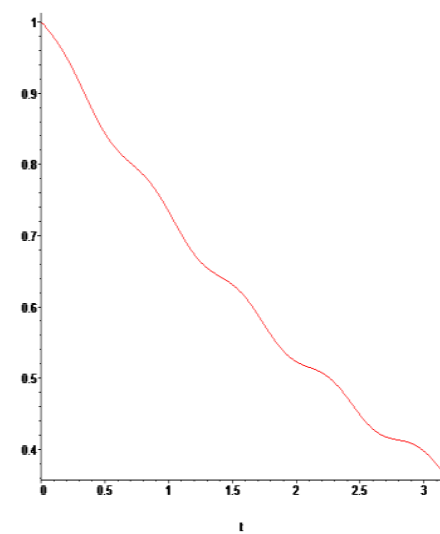

Gambar $7\left(F_{0}=25\right)$

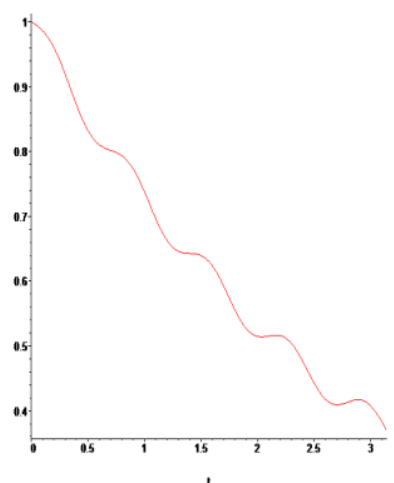

Gambar $8\left(F_{0}=50\right)$

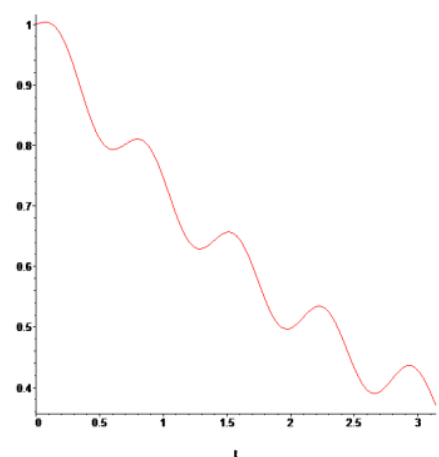

Gambar $9\left(F_{0}=100\right)$

Pada kondisi III dilakukan simulasi perhitungan untuk nilai $\omega=9<\psi=16$ dengan nilai $F_{0}$ yang semakin besar yakni $25,50,100$. Pada gambar 7 terlihat bahwa getaran cenderung teredam secara linear dan pada akhirnya akan menghilang. pada kondisi III ini dengan $F_{0}=25$ getaran yang terjadi tidak mengalami kenaikan dengan kata lain getaran terus turun dan menghilang. Pada gambar 7 getaran berhenti pada titik sekitar $t=3.2$. Lebih lanjut gambar 8 dengan nilai gaya $F_{0}=50$ menunjukkan bahwa penurunan getaran tidak selinier apabila dibandingkan pada kondisi gambar 7. Pada kondisi saat $F_{0}=50$ ini getaran mengalami penurunan getaran yang lebih bervariasi dibandingakan kondisi pada saat gaya $F_{0}=25$ meski pada akhirnya getaran juga akan berhenti juga pada saat sekitar $t=3.2$. Pada gambar 8 saat $F_{0}=100$, penurunan getaran mengalami kenaikan yang cukup banyak dibeberapa titik dibandingkan dengan dua kondisi sebelumnya meskipun pada akhirnya getaran juga akan berhenti ketika $t=3.2$.

\section{KESIMPULAN DAN SARAN}

Penelitian ini menghasilkan beberapa kesimpulan dan saran yang diuraikan dalam beberapa poin-poin sebagai berikut 


\subsection{Kesimpulan}

Beberapa hal penting yang dihasilkan dari penelitian ini antara lain:

1. Model matematika yang menjelaskan redaman getaran pada sayap pesawat terbang ditunjukkan pada persamaan(4). Model ini merupakan Persamaan Differensial orde dua non homogen. Model ini diturunkan dari model sistem pegas horizontal dengan mempertimbangkan adanya redaman fluida dan gaya sinusoidal

2. Solusi umum dari model yang terbentuk ditunjukkan pada persamaan (9) yang merupakan jumlahan atas solusi homogeny beserta solusi partikulirnya. Solusi homogen dan partikulir dari model yang terbentuk masing-masing ditunjukkan pada persamaan (6) dan (8)

3. Simulasi model dilakukan untuk tiga kondisi yakni Kondisi $\mathrm{I}(\omega=\psi)$, Kondisi II $(\omega>\psi)$ dan Kondisi III $(\omega<\psi)$ dengan nilai $x(0)=1$, $\frac{d x(0)}{d t}=0$ dan $F_{0}$ yang semakin besar yakni $25,50,100$.

4. Hasil simulasi perhitungan model pada kondisi I dapat dilihat pada gambar 1, 2 dan 3, kemudian simulasi perhitungan untuk kondisi II disajikan pada gambar 4, 5, 6 serta gambar 7, 8, 9. merupakakan simulasi untuk kondisi III.

5. Pada kondisi I, semakin besar gaya $F_{0}$, maka penurunan getaran semakin tajam namun kenaikan getaran dibeberapa titik semakin tinggi sebelum pada akhirnya getaran tersebut habis. Pada kondisi II semakin besar gaya $F_{0}$, maka semakin cepet getaran hilang dan lebih cepat pula getaran mengalami osilasi secara kontinu setelahnya. Pada gambar III, berapapun nilai $F_{0}$, getaran akan habis pada saat yang bersamaan, namun dengan cara yang tidak sama yakni semakin besar $F_{0}$, semakin besar peluang getaran sempat mengalami kenaikan sebelum akhirnya turun kembali. 


\subsection{Saran}

Beberapa poin mengenai saran dalam penelitian ini antara lain:

1. Perlu dikembangkan model matematika redaman getaran pada sayap pesawat terbang yang lebih sesuai dengan kenyataan, yakni dengan memperhatikan faktor-faktor lain seperti tekanan angin, konstanta material bahan sayap pesawat dan gaya luar lain yang bekerja pada keadaan tersebut.

2. Perlu dilakukan simulasi yang lebih lengkap dan terperinci untuk melihat dengan baik perubahan getaran yang terjadi pada sayap pesawat.

\section{DAFTAR PUSTAKA}

Alligood, K. T, Sauer, T.D, dan Yorke, J.A., Chaos an Introduction to Dynamical Systems, Springer, 1993.

Agarwal, R. D dan Regan D. O., An Introduction to Differential Equation. Springer, 2008.

Anonim, Diktat Getaran Mekanik.pdf., diakses pada 27 Juli 2014.

Boyce, W.E. \& Richard, Elementary Differential Equation and Boundary Value Problem, Edisi Kelima, John Wiley and Sons, Inc., New York, 1992.

Cahyono, M. A. dan Basukesti, A., 2010. Penentuan Frekuensi Alamiah Sayap Pesawat Latih Dasar KT-1B Menggunakan Metode MYKLESTAD, Jurnal ANGKASA, 2(1) (2010).

Coddington, E. A., An Introduction To Ordinary Differential Equation, Prentice Hall, Inc., Englewood Cliffs, New Jersey, 1961.

Anonim, Mengapa Pesawat Bisa Terbang, Dunia Baca, 2012, http://duniabaca.com/mengapa-pesawat-bisa-terbang.html, diakses pada 28 Juli 2016. 
Haberman, R., Mathematical Models: Mechanical Vibration, Population Dynamics and Traffic Flow, Prentice Hall, Inc., Englewood Cliffs, New Jersey 07623, 1971.

Widowati dan Sutimin, Buku Ajar Pemodelan Matematika Analisis dan Aplikasinya, UNDIP Press, 2013. 